\title{
Human Capital and Business Growth among Muslim Women Entrepreneurs in the Eastern Province of Sri Lanka
}

\author{
M. A. C. Salfiya Ummah, Siong Choy Chong, Ali Khatibi, S.M. Ferdous Azam
}

\begin{abstract}
Human capital (HC) is regarded as an essential resource in predicting the growth of any business venture, which encompasses the continued existence of women owned or led business entities. Researching on the capability of HC of Muslim women entrepreneurs (MWEs)has since become a topic for discussion as Muslim women face inimitable challenges than the non-MWEs. This study aims to look at the impact of HC on business growth of MWEs in the Eastern region of Sri Lanka (EPSL). HC was measured using the dimensions of business education, business experience and business skills. A structured questionnaire was used to collect data from 280 MWEs who are engaged with their district chamber of commerce in the Eastern province using simple random sampling technique. Structural Equation Modeling with AMOS and SPSS 23.0 was used as the data analysis technique. The structural model showed that business experience and business skills had significant and positive relationships with business growth of MWEs, whereas business education did not significantly influence their business growth. In most of the families in the conservative Muslim community, females are often not permitted go out themselves alone and mix with their counterparts alone. Further, many families even do not allow their female children to pursue higher education and prefer them to go for early marriage instead. This situation can be observed in Sri Lankan Muslim families especially in the Eastern Province where the majority come from rural areas. MWEs, trade chambers and decision-making authorities may use this finding to gain insights and to develop strategies on HC to facilitate business growth of Sri Lankan MWES.
\end{abstract}

Keywords: human capital, business education, business experience, business skills, business growth, Muslim women entrepreneurs.

\section{INTRODUCTION}

Business entities, whether large or small, face numerous challenges today where entrepreneurs need to continuously adapt to the dynamic environmental changes for their existence or survival.One important consideration is the resources required to operate the business such as physical, financial and human resources, out of which human capital is an essential, intangible resources that enterprises rely on the growth of their businesses. In fact, many researchers found that human capital is an important component leading to

Revised Manuscript Received on November 22, 2019

* Correspondence Author

M. A. C. Salfiya Ummah, Research Scholar, Management and Science University, Malaysia, South Eastern University of Sri Lanka.

Siong Choy Chong, Finanace, Accreditation Agency (FAA), Malaysia.

Ali Khatibi, Management and Science University, Malaysia.

S.M. Ferdous Azam, Management and Science University, Malaysia. better organisational performance (Baluku, Kikoma, Bantu and Otto 2018; Davidson and Honig, 2003; Rauch and Frese, 2000).

Human capital refersto as the accumulation of knowledge and skills of any individuals (Jiang, Monica and Guo, 2012).In other words, it refers to the capability of entrepreneurs in terms of relevant knowledge, skills and abilities to perform tasksand responsibilities to achieve their business objectives. This capital is equally important for women entrepreneurs, where a considerable increase in women-owned businesses and their contributions to economic development, innovation and job establishment in many countries has been acknowledged (Dangi and Ritika, 2014; Jiang et al., 2012).

Human capital is regarded as critical for Muslim women entrepreneurs as well; in fact human capital could be more of a pressing issue for them due to the unique challenges they face as documented in the literature(Alam, Jani and Omar, 2011; Illhaamie, Arni, Rosmawani and Al-Banna, 2014; Itani, Sidani and Balbaki, 2009; Rehman and Roomi, 2012; Shmailan, 2014). Hence, Muslim women entrepreneurs may be different from non-Muslim women entrepreneurs in their capabilities of managing their dealings successfully(Nayeam, 2006). These challenges are expected to influence on their business venturing. Even though, Islam has given all rights to women and encourage towards business, still there are some issues prevailing among Muslim communities due to their specific traditions. For example, not allowing female children for higher studies, not allowing them to supporting their businesses, not permitting to go out independently to attend training and capacity development programs etc.

In the context of this study, the Muslim community is one of the minorities in Sri Lanka, making up 9.2\% of the population. About $74.9 \%$ and $15.2 \%$ are Sinhalese and Tamils, respectively[Department of Census and Statistics (DCS), 2018].Amongst the nine provinces in Sri Lanka, the Eastern province with three districts(Ampara, Batticaloa and Trincomalee) comprise the majority of Muslims, accounting for nearly $40 \%$ (DCS, 2018). Despite this, the Sinhalese topping in the number of womenentrepreneurs (53\%), followed by the Tamils (35\%) and the Muslim women entrepreneurs (12\%). In terms of gender, however, Muslim men show the greatest proportion of participation $(40 \%)$ followed by the Sinhalese (33\%) and Tamils (27\%) (Ampara, Batticaloa and Trincomalee Registry of District Chamber of Industry and Commerce, 2017). 
Although generally Islam proposes the highest privileges for women to be involved in entrepreneurship whilst obeying the rules which protect them (Ullah, Mohamed and Yosuf, 2013), family beliefs and traditions in Sri Lanka exert a huge influence on Muslim women entrepreneurs (Swati, 2018), including their abilities to apply their human capital (knowledge, skills andabilities) for the growth of their businesses. These point to the following research question: Does human capital have a significant impact on business growth of Muslim women entrepreneurs in the Eastern province of SriLanka?

The following section reviews the literature relating to human capital, business growth and their relationships, leading to the development of hypotheses tobe tested.This is followed by the methodology employed. The resulting findings are presented and discussed before the paper is concluded with implications and future research directions.

\section{LITERATURE REVIEW}

Entrepreneurship theorists suggest that persistence, pro-activeness and inventiveness are indispensable for a flourishing enterprise and its operation(Baum, Locke and Smith, 2001; Rauch \& Frese, 2000). This inferred the individual-organisational characteristics such as knowledge, skills and abilities required by successful entrepreneurs.

Humancapital has been discussed in the entrepreneurship literature forthe last few decades. It is considered as the accumulation of knowledge and skills possessed by entrepreneurs (Jiang et al., 2012), which is a vital factor that results in better business performance (Baluku et al., 2018; Colombo and Grilli, 2010; Fatoki, 2011; Jiang et al., 2012), small business success (Lerner et al., 1997; Omwega, 2013; Rauch, Freses and Utsch, 2005; Teoh and Chong, 2007) and entrepreneurial success as a whole (Davidson and Honig, 2003).

The same holds true in the context of Muslim women entrepreneurs where studies have found that human capital is an imperative variable for the success of their ventures in Bahrain (McIntosh and Islam, 2010) and Bangladesh (Sarker and Palit, 2014).Generally, entrepreneurs who possess with higher level of human capital have a comparative improvement which direct them to make better business decisions, implement innovative technologies and adapt to changes (Shrader andSiegel, 2007).

The literature proposes dimensions of human capital to include business education, business experience and business skills (Hurrng, Mas-Tur and Yu, 2012; McIntosh and Islam, 2010).The following sub-sections present the literature of these dimensions.

\subsection{Business Education}

Several studies have shown that formal and informal knowledge about the business are related to eventual growth of the business (Jiang et al., 2012; Kor, Mahoney and Michael, 2007; McIntosh and Islam, 2010). Kor et al. (2007) found that educational level, which reflectsthe cognitive abilityand skills of an individual, helps to explain the determination of organisational level heterogeneity in entrepreneurial actions. Specifically, women entrepreneurs with higher graduate degrees tend to demonstrate greater extent of self-reliance in their works and ability to drive a successful business Gundry and Welsch, 2001; McElwee and Al-Riyami, 2003). In addition, relevant business knowledge of individuals acquired by means of education influences their business actions, aswell as the direction for favourable business growth(Kor et al., 2007;Zahra, Sapienza and Davidson,2006).However, some studies(e.g. Dharmaratne, 2012;:Lerner, Brush and Hisrich, 1997) found no significant influence of education on business performance, indicating that the evidence available is mixed with no conclusive findings.

Studies on Muslim women entrepreneurship suggest that professional education is essential for better performance of Muslim women entrepreneurs(Al-Sadi et al.,2011). Islam emphasises the necessity of business education amongst Muslims in shaping their characters such as good or bad and permissible or permissible actions. Some examples include knowledge about halal(permissible in Islam), efficient resource utilisation, trustworthy (keeping promises), constantly seeking for new adaption, practicing high morale value etc., which are imbued in Islamic business education.

\subsection{Business Experience}

Several studies have emphasised on the influence of previous business experience towards business growth (Dharmaratne, 2012; Fisher and Pollock, 2004; Jiang et al., 2012; McIntosh and Islam, 2010). Entrepreneurs who have prior experience relevant to business can congregate information resourcefully through their own experiences whether it is a success or failure, thus leading to better and quick decision making (Fobes, 2005). This is attested by Shane (2000) where business experience and recognised blueprint of action of an entrepreneur influences successful business decisions. Likewise, women entrepreneurs with a variety of work experiences, especially industry experience, have been found to be able to show better confidence in all their efforts to make their business ventures successful (Gundry and Welsch, 2001; McElwee \& Al-Riyami, 2003), leading to the growth of their businesses(Lerner and Almor,2002).However, Lerner et al.(1997) found no significant influence of experience on business performance, implying the inconclusive findings on this area.

\subsection{Business Skills}

The magnitude of business skills such as idea generation, dealing with people, keen insights on consumer behaviour and marketing skills,as well as managing finance were also found to be associated with business growth (Dharmaratne, 2012). Women entrepreneurs with management dependability are expected to possess self-reliance in their business actions to create a successful business(Gundry and Welsch, 2001; McElwee and Al-Riyami, 2003).

Accordingly, Islam guides a woman entrepreneur to involve in a business that fits with her skills (Ullah et al., 2013), knowledge about technology (Al-Sadi et al.,2011), as well as other related skills (Holmen, Thaw and Saarelainen, 2011) which are necessary to succeed in the business. 


\subsection{Business Growth}

Many researchers are having been interest on studying Business growth nowadays (Gupta et al 2013). And growth is important phenomenon for any enterprises (Machado, 2015) and it is defined as a change in size during a determined time span (Dobbs andHamilton,2007).Hence, growth or performance is a vital indicator of a prosperous enterprise.

Quantitative or financial measures can be measured using financial performance such as return on asset, return-on-investment, return-on-equity etc, whereas the qualitative of subjective measures to business performance are non-financial parameters which are attributed tothe changes in the spot of enterprise after its operation for morethan three years(Maharati, 2010). In the case of women entrepreneurs, business performance is measured based on the entrepreneurial actions which are often instrumental in delivering success (Ahamed, Bilal, Kahat, and Mutanza, 2012). Islam et al. (2011) define performance/growth as the ability of firms to create acceptable outcomes and actions. The most frequently used operationalisation of performance includes growth in some indicators such as sales, employees, profitability, assets and firm value (Achtenhagen et al., 2010). Brush et al.(2009) have examined as a geographical extension inclusion of new market and clients, and increase in the number of product and/or services, whereas Chaganti andParasuraman(1994) examined financial performance and documented organisational factors as they relate to growth.

On the basis of the literature, this study defines business growth of Muslim women entrepreneurs as including the expansion of the enterprise in terms of sales, profit and net asset growth, aswell as increase in number of employees, customers and number of products or services for at least three years of their business operations. Hence, subjective measures were used to measure the business growth of Muslim womenentrepreneurs in this study.

\subsection{Posited Relationship between Human Capital and Business Growth}

Previous literature suggests that education (Al-Sadi et al., 2011; McIntosh and Islam, 2010), business experience (Mathew, 2010) and business skills are essential for better performance of Muslim women entrepreneurs. To test the relationships and to address the inconclusive findings on business education and business skills, the following hypotheses are put forth:

H1: Business education has a significant influence on business growth of Muslim women entrepreneurs in the Eastern province of SriLanka.

H2: Business experience has a significant influence on business growth of Muslim women entrepreneurs in the Eastern province of SriLanka.

H3: Business skills have a significant influence on business growth of Muslim women entrepreneurs in the Eastern province of SriLanka.

\section{METHODOLOGY}

\subsection{Sample Size}

A sampling frame of 280 respondents was determined using the stratified random sampling technique. The criteria for sample selection included businesses owned by Muslim women entrepreneurs which have been registered with any chamber and run for more than three years. Table1 shows the demographic characteristics of the respondents.

Table 1:Demographic Characteristics ofRespondents

\begin{tabular}{lcc}
\hline Demographic Variable & Frequency & Percentage \\
\hline District & 103 & 36.8 \\
Ampara & 95 & 33.9 \\
Batticaloa & 82 & 29.3 \\
Trincomalee & & \\
\hline Age & 27 & 9.6 \\
Below 30 years & 57 & 20.4 \\
30-40 years & 121 & 43.2 \\
40-50 years & 75 & 26.8 \\
Above 50 years & & \\
\hline Marital Status & 152 & 54.3 \\
Married & 31 & 11.1 \\
Unmarried & 97 & 34.6 \\
Widowed/Divorced & & \\
\hline Education Level & 149 & 53.2 \\
Below G.C.E.(O/L) & 62 & 22.1 \\
G.C.E.(O/L) & 51 & 18.2 \\
G.C.E.(A/L) & 18 & 6.4 \\
Degree and above & & \\
\hline Business Type & 66 & 23.6 \\
Manufacturing & 43 & 15.4 \\
Craft \& arts & 70 & 25.0 \\
Services & 54 & 19.3 \\
Retail/Wholesale & & \\
business & & \\
Agri-business & 47 & 68.9 \\
\hline Number of Employees & & 27.9 \\
Below 10 & 193 & 3.2 \\
11-50 & 78 & 34.8 \\
51-200 & 9 & \\
\hline Business Experience & & \\
3-6years & 39 & \\
7-10years & 145 & \\
more than10 years & 96 & \\
\hline & & \\
\hline & & \\
\hline
\end{tabular}

The majority of respondents are from the Ampara district, followed by Batticaloa and the Trincomalee districts. Most of the Muslim women entrepreneurs go to the age group of 40-50 years, followed by those of above 50 years old. It canbe inferred that, the majority of Muslim women entrepreneurs are 40 years old or older. The majority of them are also married, followed by those who are widows or divorcees and possess educational qualifications below the General Certificate of Education (Ordinary Level). Those with degrees only constitute $6.4 \%$ of the respondents. Taken together with marital status, this shows the tradition of Muslim communities which does not encourage female children to pursue higher education but go for early marriage instead, particularly those belonging to the older generation.

Many of them are involved inthe service industry, followedby the manufacturing, retail/wholesale and the 
agribusiness industries with less than 10 employees, indicating the micro size of their enterprises. The majority of businesses have been around for seven or more years, representing $86.1 \%$ of the Muslim women entrepreneurs.

\subsection{Data Collection}

Structured questionnaire was used as the data collection technique. Section one of the questionnaire included questions on demographic information suchas district, age,marital status, education level, type ofbusiness, number of employees, years of experience. Section two comprises items measuring business education (five items), business experience (five items), business skills (eight items), whilst section three contains six items measuring business growth. The scale designed by Dharmaratne (2012) was adapted for the sub-variables of education and experience, whilst the scale designed by Maharati and Nazemi (2012) was adapted to measure the sub-variable of business skills with little modification to suit the context of Sri Lankan Muslim women entrepreneurs. Five-point Likert scale was used from strongly disagree to strongly agree in the data collection. Face validity ofthe questionnaire was also tested getting opinion from the industry experts and relevant academics in this area before issuing the questionnaires.

\subsection{Data Analysis Methods}

Structural equation modeling (SEM) with AMOS and Statistical Package for Social Science (SPSS) version 23.0software was employed to confirm the measurement model and to test the hypotheses constructed.

\subsection{Measurement model}

The data were analysed using the two-method approach (Hair, Black, Barry and Anderson, 2010). In the first approach, confirmatory factor analysis (CFA) was used to determine the sufficiency of the measurement model, after which thesecond approach, i.e. the structural model, was performed using SEM to test the hypotheses. Hair et al. (2010) suggest three or four indices to ascertain model fit of the proposed model and for the recommended fit indices to include relative chi square, $\left(\mathrm{X}^{2} / \mathrm{DF}\right)$, Root Mean Square Error of Approximation(RMSEA) and any one or two from goodness-of-fit index(GFI), adjusted goodness-of-fit index (AGFI), comparative-fit-index (CFI), normal-fit-index (NFI) and Turker-Lewis index (TLI). The relative chi-square is recommended to be less than 3.0, whereas GFI,AGFI,CFI,IFI,NFI, and TLI should be greater than 0.90. Similarly, RMSEA and RMR are considered to be a good fit when the indices are less than 0.08 (Byrne, 2010; Hair et al.,2010).

The CFA was performed with the human capital construct (with the three sub-variables) as the exogenous variable and business growth is the endogenous variable of this study.Figure1 indicates thatthe model fit the data for the measurement model as follows: with $x^{2}(\mathrm{df}=237)=416.057$; $\mathrm{p}=0.000 ; \quad x^{2} / d f=1.764 ; \mathrm{CFI}=0.972 ; \quad$ IFI=0.972; $\mathrm{RMSEA}=0.051$. At least three indices passed the cut-off value, including RMSEA of 0.051 .

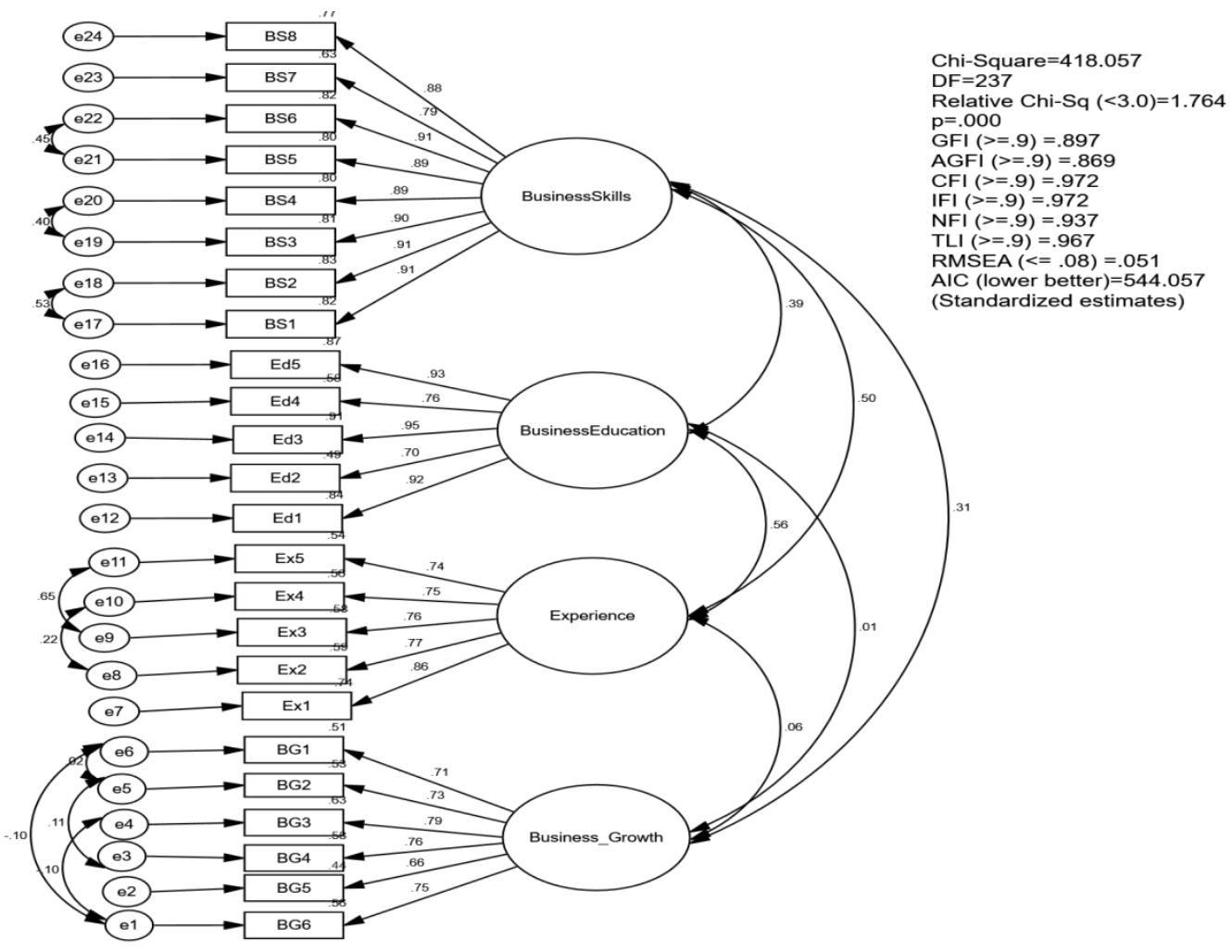

Figure 1: Measurement Model 


\section{FINDINGS}

Figure2depicts the path between the exogenous and endogenous variables.It showed that themodel fit the data for the structural model in an acceptable level as follows: $x^{2}$ $(\mathrm{df}=238)=558.670 ; \quad \mathrm{p}=0.000 ; x^{2} / d f \quad=2.347 ; \quad \mathrm{CFI}=0.950$;
$\mathrm{IFI}=0.950 ;$ RMSEA $=0.068$. It also showed that at least three indices passed the cut-off value, including RMSEA of 0.068 . Hence, the structural model can be used for hypotheis testing.

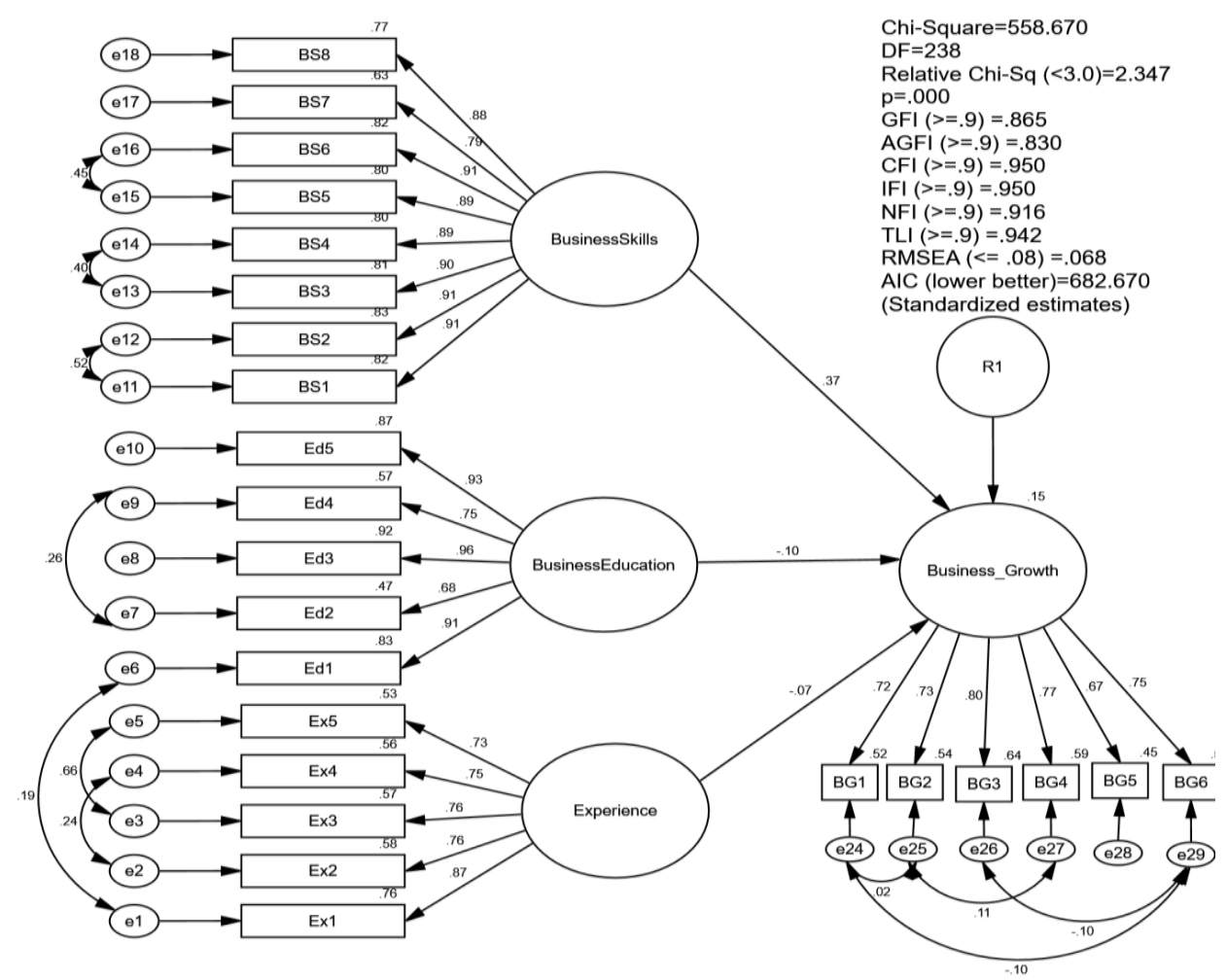

Figure2: Structural Model for the Human Capital Factors and Business Growth

Accordingly, the path between the exogenious and endogenious variables was derived from the structural model (Table2). Table 2 shows that business skills and business experience signicantly influence business growth, whilst business education was not significant, all at 0.05 level of significance. Hence, the study found support for $\mathrm{H} 2$ and $\mathrm{H} 3$ but not $\mathrm{H} 1$.

Table2: Regression Weights in the Hypothesised Path Model

\begin{tabular}{|c|c|c|c|c|c|c|c|}
\hline & & & $\begin{array}{c}\text { Std.Reg. } \\
\text { Estimat } \\
\text { e }\end{array}$ & $\begin{array}{c}\text { Estimat } \\
\mathrm{e}\end{array}$ & $\begin{array}{l}\text { S.E } \\
\cdot\end{array}$ & $\begin{array}{l}\text { C.R } \\
\cdot\end{array}$ & $\mathrm{P}$ \\
\hline BusinessGrowth & $\begin{array}{l}<- \\
-\end{array}$ & BusinessEducation & -.058 & -.043 & .045 & -.960 & $\begin{array}{c}.33 \\
7\end{array}$ \\
\hline BusinessGrowth & $\begin{array}{l}<- \\
-\end{array}$ & $\begin{array}{l}\text { BusinessExperienc } \\
\text { e }\end{array}$ & .171. & .121 & .044 & 2.730 & $\begin{array}{c}.00 \\
6\end{array}$ \\
\hline BusinessGrowth & $<-$ & BusinessSkills & .164 & .223 & .088 & 2.547 & $\begin{array}{c}.01 \\
1\end{array}$ \\
\hline
\end{tabular}

Figure 3 shows the path diagram for human capital and business growth.

\begin{tabular}{|c|c|c|}
\hline \multirow{2}{*}{ Business Education } & $B=0.058$, & \\
\hline & $\mathrm{p}=0.337)$ & \\
\hline Business Experience & $\begin{array}{l}p=0.1 / 1 \\
p=0.006\end{array}$ & Business Growth \\
\hline Business Skills & $\begin{array}{l}(\beta=0.164, \\
p=0.011)\end{array}$ & \\
\hline
\end{tabular}

Figure 3: Path Diagram

\section{DISCUSSION AND IMPLICATIONS}

Using a robust data analysis technique, this study has confirmed the importance of business experience and business skills to the business growth of Muslim women entrepreneurs but continued to provide inconclusive finding onthe relationship between business education and business growth. This finding seems to make sense as the majority of Muslim women entrepreneurs themselves do not possess high educational level and yet they have been successful in their ventures (judging from the number of years in 
business). The same finding is observed in studies on Irani (Lerner et al., 1997) and Sri Lankan (Dharmaratne, 2012) women entrepreneurs.

On the other hand, business experience is perceived by the Muslim women entrepreneurs as a more important human capital to their business growth. Based on the number of years they operated their business, they realise the importance of business experience. Many Muslim men entrepreneurs have been relying on the assistance from their spouses and children (including daughters in their childhood years) in their trades and hence, this allows the women to acquire experience from running a business. It may also suggest the reason for why experience is significant but not educational level.

Similarly, business skills have also been found to significantly influence business growth of the Muslim women entrepreneurs. This can be explained from the fact that since many women have been involved in assisting their husbands in business, they picked up the relevant skills as well such as marketing, operations, human resources, quality and other technical skills. Itis interesting to make a note of that, business skills scored a higher mean value (3.8634 \pm $0.998)$ compared to business experience $(3.643 \pm 1.098)$ and Business education $(3.597 \pm 1.128)$ implying that business skills are more important than just merely possessing experience and education.

The findings ofthe study serve asa guide to nascent as wellas prospective Muslim women entrepreneurs to develop their weaknesses based on what has been identified in this study and better support the recommendations in terms of roles of family members and spouses as well the social stigma posed by the community to design educational campaign specially for Muslim women. Experiences may be shared among female members in the Muslim female and community by means of establishing network within the familial sources as well as non familial sources which may create a platform to enhance their experiences. To enhance their skills in relation with planning, marketing, effective customer handling, technical skills, record keeping etc, skill development supportive programs may be designed by relevant authorities. The Sri Lankan government, as well as non-government decision making authorities also could use the findings to develop policies that will assist and encourage women entrepreneurs, especially the Muslim women entrepreneurs in the area of development such as organising training and capacity building programmes and in designing Business Development Support (BDS) services.

\section{CONCLUSION AND DIRECTIONS FOR FUTURE RESEARCH}

This study has revealed that, studying business growth from quantitative paradigm with the use of SEM - AMOS which helps to determine the relationship between the human capital factors and business growth of MWEs in EPSL rather than usinga qualitative approach. Thus, this study aimed to find the impact of human capital factors such as business education, business experience, and business skills on business growth of Sri Lankan Muslim women entrepreneurs.

Hypothesis 1 examined the impact on business education on business growthof MWEs in EPSL to achieve the objective 1 in this study. The education about business knowledge which were obtained through formal and or informal education or training and development did not influence among Sri Lankan Muslim women entrepreneurs $(\beta=-0.058, p=0.337>0.05)$. Thus, education did not have an impact on business education. Hypothesis 2examined the relationship between business experience and business growth to achieve the objective 2 in thisstudy. The results indicated that, business experience had significant impact of on business growth of MWEs in EPSL $(\beta=0.171, \mathrm{p}=0.006$ $<0.05)$. Similarly, hypothesis 3 examined the association of business skills and business growth to achieve the objective 3 inthis study and based on the findings of this study, business skills also had significant association with business growth of Muslim women entrepreneurs in Sri Lanka $(\beta=0.164$, $\mathrm{p}=0.011<0.05$ ). Hence, human capital factors of Sri Lankan Muslimwomen entrepreneurs have significant impact on growth of which business skills and business experience had significant positive impact on business growth where education was not significantly impact on business growth in this study. The implication of this study emphasizes that, research in business growth through organizational characteristics requires adequate understanding of human capital factors namely business experience and business skills among MWEs.

There are some limitations in the areas of theoretical background, methodology and scope of the study which needs to be addressedin future studies.

The findings of the study revealed that the strength of business skill among human capital factors on business growth is higher in order amongst all the variables studied, followed by business experience and business education. The strength of the order of variables might be re-examined by the future researchers, including adding more variables such as training and competencies and attributes to the model.

Also, this research is limited to Muslimwomen entrepreneurs registered with the District Chamber of Commerce and Industry in the three districts of the Easternprovince of Sri Lanka. Hence, it disregards Muslim women entrepreneurs who have not been registered with the District Chamber of Commerce and Industry. So future researcher may take it into account for further research. Further, this study only considered about the Muslimwomen entrepreneurs in Eastern province of SriLanka. Future studies might consider comparative studies with other ethnic group or provinces across other countries.

\section{REFERENCES}

1. Alam, S.S., Jani, M.F.M.\& Omar, N.A. (2011). An empirical study of success factors of women entrepreneurs in Southern region in Malaysia. International Journal of Economics and Finance, 3(2),166-175.

2. Al-Sadi. R., Belwal, R. \& Al-Badi, R. (2011). Women entrepreneurship in the Al-Batinah region of Oman: An identification for barriers. Journal of International Women Studies, 12(3),58-75.

3. Annual Report, Department of Census and Statistics (DCS), Sri Lanka (2018).

4. Baluku, M.M., Kikoma, I.F., Bantu C. \& Otto, K. (2018). Journal of Global Entrepreneurship Research, 8(26), 1-25.

5. Baum, J. \& Locke, E.A., \& Smith, K. (2001). A multi-dimensional mode of venture growth. Academy of Management Journal. 44(2), 292-303.

6. Dangi, N.\&Ritika (2014). Women entrepreneurship and growth and performance of MSMEs in India. International Journal of Advanced Research in Computer Science and 
Management Studies, 2(4),174-182.

7. Davidson, P. \& Honig, B. (2003). The role of social and human capital among nascent entrepreneurs. Journal of Small Business Venturing, 18,301-331.

8. Dharmaratne, K.L.B.G. (2012). Impact of individual factors on the business performance of women entrepreneurs in Sri Lanka. Sabaragamuwa University Journal, 11(1), 139-165.

9. Forbes, D.P. (2005). Managerial determinants of decision speed in new ventures. Strategic Management Journal, 26(4),355-366.

10. Gundry, L.\&Welsch, H.P.(2001). The ambitious entrepreneur: High growth strategies of women owned enterprises. Journal of Business Venturing, 16(5),453-470.

11. Hair, J.F., Black, W.C., Barry, B.J.\& Anderson, R.E. (2010). Multivariate Data Analysis, $7^{\text {th }}$ Ed.,Prentice Hall, New Jersey.

12. Ilhaamie. A.G.A., Arni, B.S., Rosmawani, C.H.\& Al-Banna, M.H. (2014).Challenges of Muslim women entrepreneurship. International Journal of Management and Technology, 5(6),428-433.

13. Itani, H.Sidani, M.Y.\&Balbaki, I. (2009). UAE female entrepreneurs: Motivations and frustrations.Equality, Diversity, and Inclusion: An International Journal, 30(5),409-424.

14. Jiang, C.X., Monica, A. \& Guo, C. (2012). Growth of women-owned businesses: The effect of intangible resource and social competence in women-owned businesses. Journal of Business Diversity, 12(1), 47-71.

15. Kor, Y.Y., Mahoney, J.T. \& Michael, S.C. (2007). Resources, capabilities and entrepreneurial perceptions. Journal of Management Studies, 44(7),1187-1212.

16. Lerner M., Brush C. \&Hisrich, R. (1997). Israeli women entrepreneurs: An examination of factors affecting performance. Journal of Business Venturing, 12,315-337.

17. Maharati, Y. \& Nazemi (2012). Entrepreneurial Drivers, Organizational functions and success of Iranian entrepreneurs. Advances in Management and Applied Economics. 2(2), 147-177.

18. Mathew, V. (2010). Women entrepreneurship in Middle East: Understanding barriers and use of IT for entrepreneurship development. International Entrepreneurship Management Journal, 6, 163-181.

19. McElwee, G. \& Al-Riyami, R. (2003). Women entrepreneurs in Oman: Some barriers to success. Career Development International, 8(7),339-346.

20. McIntosh, J.C. \& Islam, S. (2010). Beyond the veil: The influence of female entrepreneurship in a conservative Muslim context. International Management Review, 6(1), 103-109.

21. Nayeam, R.N. (2006). Islamic Entrepreneurship: A Case Study of KSA. Unpublished $\mathrm{PhD}$ thesis, King Fahad University.

22. Omwenga, J.Q., Mukulu, E.\& Kanali, C. (2013). Towards improving the performance of women entrepreneurs in SMEs in Nairobicounty, Kenya:Policyrecommendations. International Journal of Business and Social Science, 4(9),312-316.

23. Ramana, C.V., Aryasr, A.R. \& Nagayyo, D. (2008). Entrepreneurial success in SMEs on financial and non-financial parameters. The ICFAI University Journal of Entrepreneurship Development, 1(2), 32-48.

24. Rauch, A., Frese, M., Utsch, A. (2005). Effect of human capital and long-term human resource developmentand utilisation of employment growth of small scale businesses: A causal analysis. EntrepreneurshipTheory and Practice, 681-698.

25. Rehman, S. \& Roomi, M.A. (2012). Gender and work-life balance: A phenomenological study of women entrepreneurs in Pakistan. Journal of Small Business and Enterprise Development, 19(2),209-228.

26. Sarker, S. \&Palit, M. (2014). Determinants of success factors of women entrepreneurs in Bangladesh- A study based on Khulna region. Business and Economic Research,4(2), 237-250.

27. Schneider, K. (2017). Entrepreneurial competencies of women entrepreneurs of micro and small enterprises. Science Journal of Education, 5(6), 252-261.

28. Shamailan, A. (2014). Female entrepreneurs in Saudi Arabia: A comparison of barriers and motivations: Moving from disenfranchisement to empowerment. Elite Research Journal of Education and Review, 2(2), 6-21.

29. Shane, S. \& Venkatraman, S. (2000). The promise of entrepreneurship as a field of research. Academy of Management Review, 25, 217-226.

30. SME Policy Framework. Ministry of Industry and Commerce (2014).

31. Swati, P. (2018). Constrained faced by women entrepreneurs in developing countries: Review andranking.Gender in Management: An International Journal. 33(4), 315-331.

32. Ullah, M.M., Mohamed, T. \& Yousuf, F. (2013). Women entrepreneurship: Islamic perspective, European Journal of Business Management, 5(11),253-269. 